\title{
Sero-epidemioloical survey on African horse sickness virus among horses in Khartoum State, Central Sudan
}

\author{
Siham T. Karamalla', Ahmed I. Gubran', Ibrahim A. Adam', Tamadur M. Abdalla' ${ }^{1}$ Reem O. Sinada',
} Eltahir M. Haroun ${ }^{2}$ and Imadeldin E. Aradaib ${ }^{1,2,3^{*}}$ (D)

\begin{abstract}
Background: African horse sickness virus (AHSV) is an infectious non contagious insect-transmitted double-stranded (ds) RNA orbivirus of the family Reoviridae. AHSV causes an often fatal hemorrhagic infection with high mortality among selected breeds of Arabian horses. This study was conducted to avail some information with regard to the prevalence and associated risk factors of AHSV among ecotype breeds of horses in central Sudan.

Methods: Sera were collected from 320 horses, which were selected randomly from four localities and employed in the study. A competitive enzyme-linked immunosorbent assay (CELISA) was used to screen sampled sera for AHSV-specific immunoglobulin G (lg G) antibodies.

Results: Seropositivity to AHSV Ig G was detected in 275 out of the 320 horse sera, thus accounting for a prevalence rate of $85.9 \%$. Potential risk factors to AHSV infection were reported to be associated with horse breed $(\mathrm{OR}=5.0, \mathrm{Cl}=0.07-2.104, p$-value $=0.039)$ and activity of the horse $(\mathrm{OR}=3.21, \mathrm{Cl}=0.72-1.48, p$ - value $=0.008)$.

Conclusions: The high prevalence of AHSV in Khartoum State of Central Sudan necessitates the need for continuous surveillance for AHSV infection to prevent a possible disease outbreak in this region of the African continent.
\end{abstract}

Keywords: Epidemiology, Survey, equines, AHSV, ELISA, Sudan

\section{Background}

African horse sickness (AHS) is an acute disease of horses, which most often results in death of the infected animal. The disease is caused by the African horse sickness virus (AHSV), a member of the orbivirus genus in the Reoviridae family $[1,2]$. In other equine species such as donkeys and mules, infection with AHSV is usually subclinical [3-5]. However, infected mules can amplify the virus and became seroconverted and thus play an important role in the epidemiology of the disease [6]. Nine serotypes of AHSV designated as AHSV-1 to AHSV-9 are recognized worldwide differentiated by serum neutralization test and molecular based assays [7].

\footnotetext{
* Correspondence: aradaib@yahoo.com; aradaib@uofk.edu

1 Molecular Biology Laboratory (MBL), Department of Clinical Medicine,

Faculty of Veterinary Medicine, University of Khartoum, P.O. Box 32,

Khartoum North, Sudan

${ }^{2}$ Scientific Research Directorate, Al-Mughtaribeen University, Khartoum,

Sudan

Full list of author information is available at the end of the article
}

An outbreak of AHS in a disease free region would have catastrophic effects on equine welfare and industry, particularly for international events such as the Olympic Games [8]. In areas of endemicity, AHSV is of concern to wildlife managers as an outbreak of the disease is likely to occur among the populations of zebra [9]. In addition, international trade of race horses is restricted to AHSV-free animals only [10]. AHSV is transmitted to horses by Culicoides midges, in particular by Culicoides imicola [11]. AHSV is related to bluetongue virus (BTV), epizootic hemorrhagic disease of deer virus (EHDV) and palyam serogroup of orbiviruses [11]. Whereas BTV, EHDV and Palyam viruses cause clinical diseases in ruminants, AHSV is mainly a disease of equines. AHSV induced a fatal infection in race horses in North Africa, the Middle East and different parts of the Arab world including the Sudan [12-14]. Serological evidence of AHSV infection in horses and donkeys is wide spread in the Sudan $[6,10,12]$. Multiple outbreaks

(c) The Author(s). 2018 Open Access This article is distributed under the terms of the Creative Commons Attribution 4.0 International License (http://creativecommons.org/licenses/by/4.0/), which permits unrestricted use, distribution, and reproduction in any medium, provided you give appropriate credit to the original author(s) and the source, provide a link to the Creative Commons license, and indicate if changes were made. The Creative Commons Public Domain Dedication waiver (http://creativecommons.org/publicdomain/zero/1.0/) applies to the data made available in this article, unless otherwise stated. 
and sporadic cases of AHSV were reported in Arabian horses in various states of the Sudan based on clinical presentation. However, the virus was isolated, for the first time, from whole blood and spleen of a mare in Khartoum State, Sudan [12]. Subsequently, AHSV was isolated from blood of infected horses in suckling mice (Aradaib, unpublished data). The two virus isolates were identified as AHSV serotype 9 (AHSV-9). Subsequently, sporadic cases and multiple outbreaks of AHSV were reported in different localities of Khartoum States. However, virus isolation attempts from blood and tissues of infected horses were largely unsuccessful.

Currently, the disease is diagnosed by conventional virus isolation, serology and molecular-based assays [15-19]. Virus isolation is tedious, time consuming, labor intensive and expensive $[4,19]$. Serology is useful in epidemiologic studies to identify previous AHSV infection by detection of Ig G-specific antibodies or by detection of Ig $M$ for detection of recent viral infections [20]. Several molecular-based assays were developed and evaluated for detection of AHSV serogroup and serotypes [21-26]. In previous studies, we have reported on a simple, rapid, sensitive and specific RT-PCR-assay for detection of AHSV serogroup in cell culture [6]. Subsequently, a more sensitive nested RT-PCR assay was also developed and evaluated for detection of AHSV RNA in a variety of clinical samples [10]. Currently, no information is available regarding the prevalence of AHSV or the potential risk factors associated with the disease among horses in Sudan. Therefore, the control of emerging viral pathogens, such as AHSV, is urgently needed in the country. The Sudan has a large numbers of horses, which play an important role in horse races and transport in remote areas. We believe further epidemiologic surveys including implementation of improved surveillance would be necessary to prevent further spread of the disease and to combat this important viral pathogen. The objectives of the present investigation were to determine the prevalence and identify risk factors associated with AHS among horses in Khartoum state, Central Sudan.

\section{Methods}

\section{Study area}

Khartoum State is one of the largest states in Sudan, which comprises three major cities. These cities are Khartoum, Khartoum North and Omdurman. Khartoum is the capital of Sudan and it is located in the middle of the country. The state covers an area of approximately $23,000 \mathrm{~km}^{2}\left(\mathrm{~km}^{2}\right)$. The population of Khartoum state is composed of trips from different parts of the Sudan and estimated to be nearly 6 millions. The state is located at the junction of the White Nile and the Blue Nile. In Khartoum state, the 2 Niles unite to form the river Nile, which runs to the north throughout Sudan and Egypt.
The state lies between longitudes 31.5 to $34{ }^{\circ} \mathrm{E}$ and latitudes 15 to $16^{\circ} \mathrm{N}$. The weather is very hot and dry in the summer season but cold dry in the winter season. Average rainfall reaches $150 \mathrm{~mm}$ in the north-eastern areas and $250 \mathrm{~mm}$ in the northwestern areas. The temperature in summer may reach up to $48{ }^{\circ} \mathrm{C}$ from April to June. In the winter, the temperature eventually declines to reach $15{ }^{\circ} \mathrm{C}$ between November and January. The horse population of Khartoum State is 6585 as estimated by the Sudan Ministry of Animal Resources, 2006 [9]. A map of Khartoum State representing the different localities is illustrated in (Fig. 1).

\section{Study design}

The present investigation was conducted as a cross sectional survey in Khartoum State of the Central Sudan. A multistage probability sampling method was applied in this study. Four localities in Khartoum state including Omdurman, East Nile, Bahri and Khartoum were selected randomly. Eight herds in each village of the four localities were selected. Finally, 10 blood samples were collected from horses in each herd using simple random sampling method, which accounts for a total of 320 blood sample size [27]. Horses over one year of age were considered for the purpose of this study to avoid detection of maternal AHSV antibodies in young animals.

\section{Questionnaire}

A structured questionnaire was employed for the survey and was applied to all animals participated in the study. The information required for the survey was obtained from the animal owners. Individual and management risk factor attributes were included in the questionnaire. The individual risk factors including age (younger animals $<2$ years older animals 2 years and above), sex (male, female), breed (through breed, local breed), body condition (fair and thin); and the management risk factor attributes including insect vector (presence or absence), insect control measures (practiced or not), activity of the horse such as chaser (race horse), cart horse involved in transport of materials, and police horse involved in security of the state by the police at night. In addition, the four localities were also included in the study.

\section{Ethics approval and consent to participate}

The purpose of the study was made clear to the animal owners participated in the study. Those who agreed to participate in the study were requested to provide a written consent. All the information related to the AHSV risk factors was obtained from the animal owners. The ethical clearance for the study was obtained from the Research Board of the Faculty of Veterinary Medicine, University of Khartoum, Sudan. 


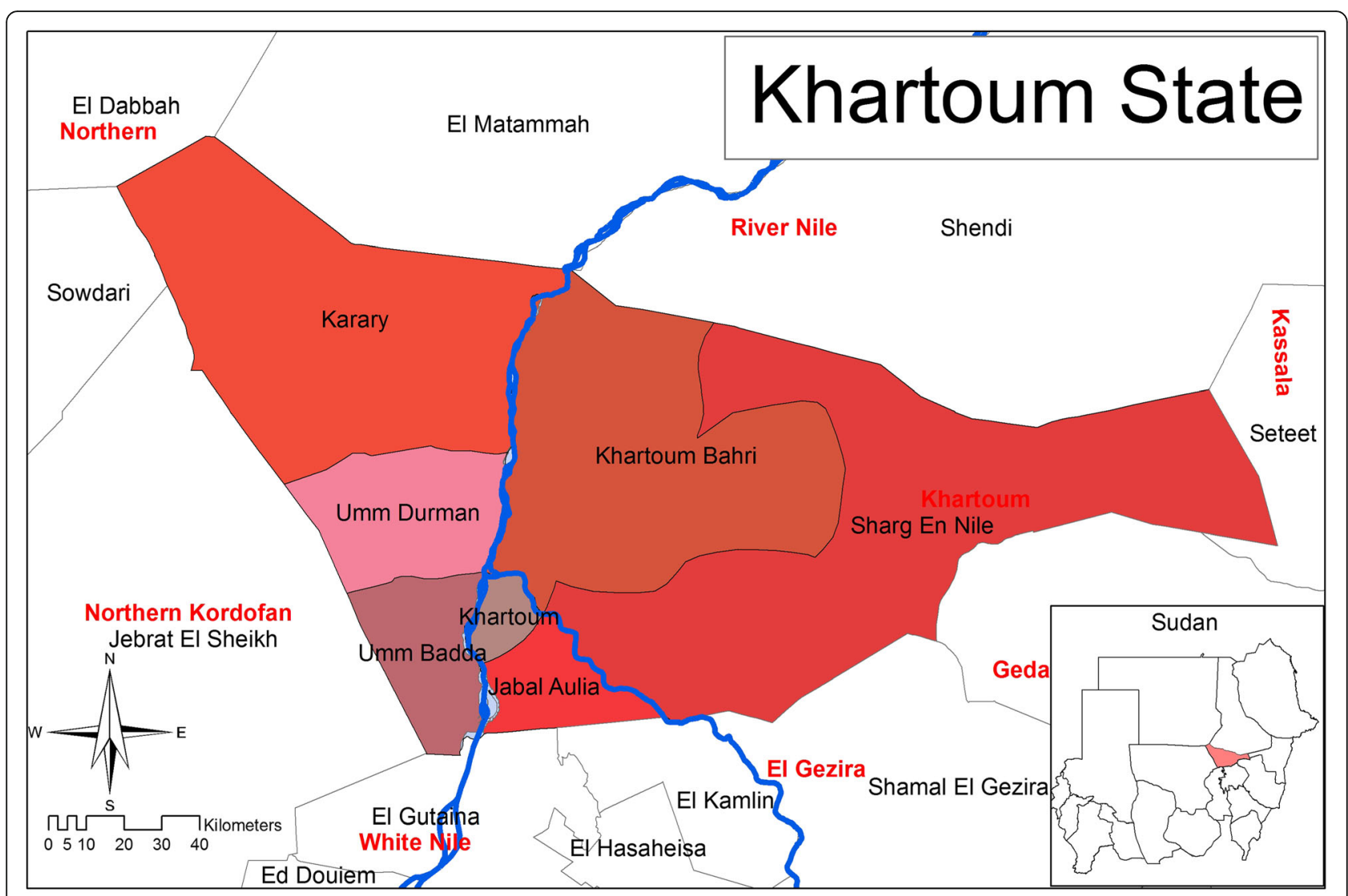

Fig. 1 A map of the localities included in the study area of Khartoum State, Sudan

\section{Collection of blood samples}

Blood samples were collected from horses by well trained veterinarians to ensure proper physical restraint of animals to avoid injury. Blood samples were collected from the jugular vein of the selected horses in the study area of Khartoum State, Central Sudan. A total number of 320 sera were collected randomly from the animals and employed in this study. Blood samples were allowed to clot and sera were separated and kept frozen at $-20{ }^{\circ} \mathrm{C}$ until used for screening of horses for seropositivity to AHSV-specific IgG antibodies using competitive indirect enzyme-linked immunosorbent assay (cELISA).

\section{Enzyme-linked immunosorbent assay (ELISA)}

Detection of AHSV-specific Ig G antibodies was made possible using a commercially available cELISA kit (Ingezim AHSV, Compact Plus, Spain). The cELISA was performed in antigen coated plates. A total of $100 \mu \mathrm{l}(\mu \mathrm{l})$ test volumes were used in the cELISA assay. All incubations were performed for $\mathrm{I} \mathrm{h}$ at $37{ }^{\circ} \mathrm{C}$ and washing of plates was performed three times with the provided washing buffer. The results of the cELISA were recorded using ELISA reader set at $630 \mathrm{~nm}$. The test sample was considered positive when the optical density is less than $50 \%$ of the mean of the negative controls.

\section{Statistical analyses}

Statistical package for social sciences (SPSS) software package for window (version 21.0) was employed to enter the data in the computer. The univariable analysis using Chi-square $\left(\chi^{2}\right)$ test was used to determine the associations between the outcome variable (status of AHSV seropositivity in horses) and its potential risk factors. Significant association between AHSV and risk factor was initially considered when $P$ value $<0.25$ (two tailed; $\alpha=0.25$ ). The results of the univariable analysis were further subjected multivariable analysis using logistic regression. Results were expressed as odd ratios (OR) with 95\% confidence intervals (C.I) for each risk factor. $P$ value less than $0.05(p<0.05)$ represents significant association between the AHSV seropositivity and associated risk factors.

\section{Results}

AHSV seropositivity was recorded in 275 out of the 320 horses as detected by the cELISA, which accounts for prevalence rate of $85.9 \%$. The highest rates of AHSV seropositivity was recorded in East Nile locality (94\%) whereas the lowest rate of seropositivity was recorded in Bahry locality (81.5\%). The univariate analysis using Chi-square test was conducted for the association between the potential risk factors and 
AHSV seropositivity. The initial results using univariate analysis showed that the independent variables including, body condition, breed, activity of the horse, presence of insects and locality were statistically significant $p>0.25$ (Table 1 ). The significant results in the univariable model were further re-entered into final multivariate model using logistic regression analysis to illuminate confounding factors. A $p$-value $<0.05$ was considered statistically significant. Horse breed $(\mathrm{OR}=5.0$, $\mathrm{CI}=0.07-2.104, p$-value $=0.039)$ and activity of the horse $(\mathrm{OR}=3.21, \mathrm{CI}=0.72-1.48, p$ - value $=0.008)$ were recorded as potential risk factors for contracting AHSV infection. The results are summarized in (Table 2). The rest of the risk factors did not show any significant association with AHSV seropositive horses.

\section{Discussion}

Infectious viral pathogens, such as AHSV, are reemerging as major veterinary problems in different parts of the African continent $[13,14]$. Very little information is available about the epidemiology of AHSV in the Middle East and East Central Africa including the Sudan. To better predict and respond to AHSV outbreak, this cross sectional study has been initiated to estimate the prevalence of AHSV and to identify the potential risk factors associated with the disease among horses in Khartoum State of the Central Sudan. The study area of Khartoum state has been selected as it is considered the center for international trade of horses in the country. The routine surveillance for AHSV would be necessary to monitor incursion of the disease in other part of the country

Table 1 Univariate analysis for the association between potential risk factors and AHSV infection among horses in Khartoum state, Sudan, using chi-square test

\begin{tabular}{|c|c|c|c|c|c|}
\hline Risk factors & Animals tested & Animals affected (\%) & df & $x^{2}$ & $p$-value \\
\hline Locality & & & 3 & 6.7 & 0.079 \\
\hline East Nile & 50 & $47(94 \%)$ & & & \\
\hline Bahry & 108 & $88(81.5 \%)$ & & & \\
\hline Omdurman & 35 & $33(94 \%)$ & & & \\
\hline khartoum & 127 & 107(84\%) & & & \\
\hline Age & & & 1 & 0.29 & 0.58 \\
\hline young & 89 & $78(87.6 \%)$ & & & \\
\hline Old & 231 & 197(85.3\%) & & & \\
\hline Sex & & & 1 & 0.70 & 0.48 \\
\hline Female & 50 & $41(82 \%)$ & & & \\
\hline Male & 270 & 234(86.7\%) & & & \\
\hline Breed & & & 2 & 7 & 0.031 \\
\hline Arabi & 14 & $12(85.7 \%)$ & & & \\
\hline Cross & 30 & $21(70 \%)$ & & & \\
\hline Local & 276 & $242(87.7 \%)$ & & & \\
\hline Body condition & & & 1 & 4.6 & 0.03 \\
\hline Fair & 294 & $249(84.7 \%)$ & & & \\
\hline Thin & 26 & $26(100 \%)$ & & & \\
\hline Presence of insects & & & 1 & 1.94 & 0.16 \\
\hline No & 33 & $31(93.9 \%)$ & & & \\
\hline Yes & 287 & $244(85 \%)$ & & & \\
\hline Control measures & & & 1 & 0.49 & 0.48 \\
\hline No & 193 & 168(87\%) & & & \\
\hline Yes & 127 & 107(84.3\%) & & & \\
\hline Activity & & & 2 & 6.01 & 0.049 \\
\hline Chaser & 73 & $60(82.2 \%)$ & & & \\
\hline Cart horse & 108 & $88(81.5 \%)$ & & & \\
\hline Police horse & 139 & 127(91.4\%) & & & \\
\hline
\end{tabular}


Table 2 Multivariate analysis using logistic regression model for significant association ( $p>0.05$ ) between risk factors and AHSV infection among Horses in Khartoum State, Sudan

\begin{tabular}{|c|c|c|c|}
\hline Risk factors & OR & $95 \% C ।$ & $P$-Value \\
\hline \multicolumn{4}{|l|}{ Breed } \\
\hline Cross & Reference & & \\
\hline Arabi & 5 & $0.07-2.104$ & 0.039 \\
\hline \multicolumn{4}{|l|}{ Activity } \\
\hline Cart horse & Reference & & \\
\hline Chaser & 3.21 & $0.072-1.48$ & 0.008 \\
\hline
\end{tabular}

considered to be AHSV- free zones. The present study showed that the prevalence of AHSV seropositivity is gnificantly high $(85.9 \%)$. The detection of AHSV antibodies indicated previous exposure of horses to AHSV. The high prevalence rate (85.9\%), as indicted by detection of AHSV antibodies, showed an evidence of previous circulation of AHSV in the study area. There is no vaccination program for AHSV in the Sudan. Therefore, the detected antibodies were due to natural infections. It should also be noted that detection of maternal antibodies to AHSV was excluded as horses included in this study aged over one year.

The present study showed that there was a significant difference between the AHSV seropositivity rate and the breed of the horse. Exotic (Cross) breed of horses are at 5 times at risk compared to indigenous (local) breed of Sudanese horses. High seroprevalence was observed among cross breeds with high percentage of exotic blood. Exotic breeds are usually highly susceptible to bites of insect vectors and subsequent development of AHSV infection. In contrast, the indigenous breed of horses are relatively resistant to bites of insect vectors hence, they were at lower risk for the disease compared to cross breed. In addition, there was a significant difference between AHSV seropositivity and the activities of the horse, particularly those involve in horse racing. Race horses are at 3 times more likely to be at risk compared to other horses involved in transportation activities. Once again, this is attributed to the fact that almost all race horses are of the Arabian horse origin or imported from other countries. It is also possible that most race horses are not usually kept in insect-secured houses and are likely to be exposed to the insect vector as is the case in most horse houses in Khartoum State. The highest rates of AHSV seropositivity was recorded among horses in the East Nile locality (94\%). This is most probably to construction of irrigation projects and agricultural schemes in this locality, which provide conducive environmental condition for the breeding of Culicoides midge, the insect vector. However, the lowest seropositivity rate was recorded among horses in Bahry locality (81.5), which is possibly attributed to dry climate condition and high variations in temperatures. The present study illustrated that AHSV is now becoming broadly distributed in Sudan with a very high prevalence rate of $85.9 \%$ in Khartoum state. It is recommended that the survey should be extended in the future to include virus isolation attempts and to identify the AHSV serotypes circulating in the country. Molecular epidemiological studies such as, viral sequence analysis and phylogeny, should be conducted to monitor the movement of the virus between these African countries. The rest of the individual or management risk factors did not show any significant association with HSV seropositivity. Male or female horses have no significant association with AHSV seropositivity. In addition, no significant difference was observed between AHSV seropositivity and the age of the animals. A Previous study on Seroprevalence of the disease in Ethiopia reported that age and sex were not significantly associated with seroprevalence of AHSV [14]. Early diagnosis during disease outbreak among non vaccinated equines would be necessary for prevention and control of the disease [28]. Complete viral genome sequencing and phylogeny would be necessary to determine the virus genetic lineages [29]. It should be noted that treatment of horses with insecticides be applied monthly to prevent insect bite. The animal owners should also be educated about the risks of the disease, and prevention of the infection through insect control program.

\section{Conclusions}

The prevalence of AHSV is significantly high (85.9\%) among horses in Khartoum State, Sudan. Exotic Breed and activity of the horse particularly those involved in racing activity are considered to be at higher risk of contracting AHSV infection. This study would be expected to reduce the impact of the disease on horse breeders and subsequently avoid a possible AHSV outbreak among horses. Virus isolation attempts would be necessary for subsequent molecular characterization studies. It is recommended that complete viral genome sequencing and phylogenetic studies should be conducted to determine the genetic lineages of AHSV serotypes circulating in Sudan to follow the movement of the virus in the African continent.

\section{Abbreviations \\ AHSV: African horse sickness virus; BTV: Blue tongue virus; Cl: Confidence interval; EHDV: Epizootic hemorrhagic disese virus; ELISA: Enzyme-linked immunosorbent assay; HRP: Horse radish peroxidase; Ig G: Immunoglobulin G; OR: Odd ratio; RT-PCR: Reverse transcriptase polymerase chain reaction; Ml: Microliter}

\section{Acknowledgements}

We thank the Police Department, Khartoum State for permission of blood collection from the police horses. The technical assistance of Mr. Abdalla M. Fadlelmoula is gratefully acknowledged.

Availability of data and materials

Data and materials are available upon request by the corresponding author. 


\section{Authors' contributions}

STK, AIG, IAA helped with collection of blood samples from horses and the design of the study. TMA, STK and ROS performed the laboratory work including ELISA assay. IEA and EMH analyzed the data. All authors have read and approved the final version of this manuscript.

\section{Ethics approval and consent to participate}

Collection of blood from horses was performed by qualified veterinarians following proper physical restraint of animals to ensure both personnel and animal safety. Animal owners were explained the study purposes before procedures and upon agreeing to participate, they provided a written consent prior to study procedures and blood collection from their animals. The study received ethical clearance from the Research Board of the Faculty of Veterinary Medicine, University of Khartoum, Sudan. The risk factor information was obtained from the animal owners through the structured questionnaire form, which permitted the use of the blood samples for diagnostic and research purposes.

\section{Consent for publication}

Not applicable.

\section{Competing interests}

The authors declare that they have no competing interests.

\section{Publisher's Note}

Springer Nature remains neutral with regard to jurisdictional claims in published maps and institutional affiliations.

\section{Author details}

'Molecular Biology Laboratory (MBL), Department of Clinical Medicine, Faculty of Veterinary Medicine, University of Khartoum, P.O. Box 32, Khartoum North, Sudan. ${ }^{2}$ Scientific Research Directorate, Al-Mughtaribeen University, Khartoum, Sudan. ${ }^{3} \mathrm{EBH}$ Scientific Research Laboratory, Zamzam University College (ZUC), Khartoum, Sudan.

Received: 22 August 2017 Accepted: 24 July 2018

Published online: 01 August 2018

\section{References}

1. Borden EC, Shope RE, Murphy FA. Physicochemical and morphological relationships of some arthropod-borne viruses to bluetongue virus-anew taxonomic group. Physicochemical and serological studies. J Gen Virol. 1971;3:261-71

2. Fenner F, Pereira HG, Porterfield JS. Family and generic names for virus approved by the International Committee on Taxonomy of Viruses. Intervirology. 1974;3:193-4.

3. Abuelzein EME, Mirghani ME, Ali BE. Observations on African horse sickness in donkeys in the Sudan. Rev Sci Tech Off Int Epiz. 1989:8:785-7.

4. El-Hasnaoui H, el Harrak M, Zientara S, Laviada M, Hamblin C. Serological and virological responses in mules and donkeys following inoculation with African horse sickness virus serotype 4. Arch Virol. 1998;14:29-36.

5. Fassi-Fihri O, el Harrak M, Fass-Fehri MM. Clinical, virological and immune responses of normal and immunosuppressed donkeys (Equus asinus africanus) after inoculation with African horse sickness virus. Arch Virol Suppl. 1998;14:49-56.

6. Aradaib IE, Mohammed EHM, Ali NOM, Majid AA, Idris SH, Karrar AE. A simple and rapid method for detection of African horse sickness virus serogroup using RT-PCR. Vet Res Comm. 2006;30:319-24.

7. Sailleau C, Hamblin C, Paweska JT, Zientara S. Identification and differentiation of nine African horse sickness virus serotypes by RT-PCR amplification of the serotype-specific genome segment 2. J Gen Virol. 2000;81:831-7.

8. Robin M, Page P, Archer D, Baylis M. African horse sickness: The potential for an outbreak in disease-free regions and current disease control and elimination techniques. Equine Vet J. 2016;48:659-69.

9. Becker E, Venter GJ, Greyling T, Molini U, van Hamburg H. Evidence of African horse sickness virus infection of Equus zebra hartmannae in the south-western Khomas Region, Namibia. Transbound Emerg Dis. 2018;65(1): 278-80. https://doi.org/10.1111/tbed.12651.

10. Aradaib IE. PCR detection of African horse sickness virus based on genome segment three sequence analysis. J Virol Method. 2009;159:1-5.
11. Mohammed EHM, Mellor PS. Further studies on bluetongue-related Orbiviruses in the Sudan. Epidemiol \& infect. 1990;105:619-32.

12. Eisa M. The isolation and identification of type 9 African horse sickness virus in the Sudan. Br Vet J. 1974;130:606-10.

13. Ayelet G, Derso S, Jenberie S, Tigre W, Aklilu N, Gelaye E, Asmare K. Outbreak investigation and molecular characterization of African horse sickness virus circulating in selected areas of Ethiopia. Acta Trop. 2013;127:91-6.

14. Bitew M, Andargie A, Bekele M, Jenberie S, Ayelet G, Gelaye E. Serological survey of African horse sickness in selected districts of Jimma zone, Southwestern Ethiopia. Trop Anim Health Prod. 2011;43:1543-7.

15. Hamblin C, Mertens PPC, Mellor PS, Burroughs NJ, Crowther JR. A serogroup specific enzyme-linked immunosorbent assay for the detection and identification of African horse sickness viruses. J Virol Methods. 1991;31:285-92.

16. Maree S, Paweska JT. Preparation of recombinant African horse sickness virus VP7 antigen via a simple method and validation of a VP7-based indirect ELISA for the detection of group-specific lgG antibodies in horse sera. J Virol Methods. 2005;125:55-65.

17. Martinez-Torrecuadrada JL, Diaz-Laviada M, Roy P, Sanchez C, Vela C, Sanchez-Vizcaino JM, Casal Jl. Serologic markers in early stages of African horse sickness virus infection. J Clin Microbiol. 1997;35:531-5.

18. Martinez-Torrecuadrada JL, Iwata H, Venteo A, Casal I, Roy P. Expression and characterization of the two outer capsid proteins of African horsesickness virus: the role of VP2 in virus neutralization. Virology. 1994;202:348-59.

19. Rodriguez $\mathrm{M}, \mathrm{Hooghuis} \mathrm{H}$, Castano M. Current status of the diagnosis and control of African horse sickness. Vet Res. 1993;24:189-97.

20. Wade-Evans AM, Woolhouse T, O'Hara R, Hamblin C. The use of African horse sickness virus VP7 antigen, synthesised in bacteria, and anti-VP7 monoclonal antibodies in a competitive ELISA. J Virol Method. 1993:45:179-88.

21. Stone-Marschat M, Carville A, Skowronek A, Laegreid W. W: detection of African horse sickness virus by reverse transcription-PCR. J Clin Microbiol. 1994;32:697-700.

22. Williams CF, Inoue T, Lucus AM, Zanotto PM, Roy R. The complete sequence of four structural proteins of African horse sickness virus serotype 6: evolutionary relationships within and between the orbiviruses. Virus Res. 1998:53:53-73.

23. Zientara S, Sailleau C, Moulay S, Plateau E, Cruciere C. Diagnosis and molecular epidemiology of the African horse sickness virus by the polymerase chain reaction and restriction patterns. Vet Res. 1993;24:385-95.

24. Zientara S, Sailleau C, Moulay S, Cruciere C. Differentiation of African horse sickness viruses by polymerase chain reaction and segments 10 restriction patterns. Vet Microbiol. 1995;47:365-75.

25. Zientara S, Sailleau C, Moulay S, Wade-Evans A, Cruciere C. Application of the polymerase chain reaction to the detection of African horse sickness viruses. J Virol Methods. 1995;1995(53):47-54.

26. Zientara S, Sailleau C, Moulay S, Cruciere C, el- Harrak M, Laegreid WW, Hamblin C. Use of reverse transcriptase-polymerase chain reaction (RT-PCR) and dot-blot hybridization for the detection and identification of African horse sickness virus nucleic acids. Arch Virol. 1998;14:317-27.

27. Martin SW, Meek HA, Willeberg P. Veterinary Epidemiology: Principles and Methods. AMES: Iowa state University Press; 1987.

28. Koekemoer JJ. Serotype-specific detection of African horsesickness virus by real-time PCR and the influence of genetic variations. J Virol Methods. 2008; 154:104-10.

29. Martin LA, Meyer AJ, O'Hara RS, Fu H, Mellor PS, Knowles NJ, Mertens PP. Phylogenetic analysis of African horse sickness virus segment 10: sequence variation, virulence characteristics and cell exit. Arch Virol. 1998;14:281-93.

Ready to submit your research? Choose BMC and benefit from:

- fast, convenient online submission

- thorough peer review by experienced researchers in your field

- rapid publication on acceptance

- support for research data, including large and complex data types

- gold Open Access which fosters wider collaboration and increased citations

- maximum visibility for your research: over $100 \mathrm{M}$ website views per year

At BMC, research is always in progress.

Learn more biomedcentral.com/submissions 